\title{
The Implementation of Supportive Classroom Environment in VII-Grade Mathematics Learning
}

\author{
Willy Abdul Ghany ${ }^{1}$, Wahyudin ${ }^{2}$ \\ 1,2Mathematics Education, Universitas Pendidikan Indonesia, Indonesia \\ 1willyghany@upi.edu, ${ }^{2}$ wahyudin mat@yahoo.com
}

\begin{abstract}
\begin{tabular}{l}
\hline \hline \\
\hline Article History: \\
Received $:$ 20-01-2021 \\
Revised : 31-03-2021 \\
Accepted $: 01-04-2021$ \\
Online : 17-04-2021 \\
\hline
\end{tabular}
Keywords:

Productive Pedagogies Framework;

Supportive Classroom

Environment;

\section{Article History}

ABSTRACT

Mathematics is seen by some students as a subject which is not easy to learn. Thus, they need someone who can make mathematics easy, in this point, a teacher. Teachers as instructor are needed to be more innovative in developing instruction that can encourage students to get an ideal learning experience. Not just regarding approaches, teaching materials, and strategies, yet additionally needs to focus on the learning environment which promotes the learning process. One of the framework that offers learning which takes into a supportive learning environment is the Productive Pedagogies Framework. The purpose of this study is to look at the implementation of learning that utilized the Supportive Classroom Environment dimension of the Productive Pedagogies Framework. This study used qualitative method. There were 33 grade VII students (boys and girls) on average age of 13 years old from one of the Junior High Schools in Bandung participated in this study. The research findings revealed that (1) implementing Supportive Classroom Environment can further encourage students in upper group to achieve more optimal learning outcomes; (2) This learning can be said to encourage middle group students to get optimal learning outcomes; (3) This learning has not been able to encourage students in lower group. We concluded that implementing Supportive Classroom Environment can further encourage students in upper and middle groups.
\end{abstract}

d.i) Crossref

https://doi.org/10.31764/jtam.v5i1.3919

\section{(c) (i) (2)}

This is an open access article under the CC-BY-SA license

\section{A. INTRODUCTION}

Students see mathematics as a subject which is not easy to learn. Mathematics is considered a difficult subject because students already claim in their minds that mathematics is a difficult and complicated science (Siregar, 2017). This opinion is in accordance with the author's experience when practicing Experience Program in one of the Junior High Schools in Bandung, many students think that mathematics is a difficult science. This assumption is likely to affect the mastery of mathematics because it begins with fear and compulsion in learning it, not based on needs to learn mathematics.

There are several factors causing this happened, such as lack of learning media, and the mindset that is embedded in the minds of students that mathematics is a difficult science (Sholihah \& Mahmudi, 2015). Other factor that must be concerned is a classroom environment which is less supportive in the process of learning mathematics. The problem of 
the classroom environment has become a widespread concern by various education educators and researchers (K. Alsharif \& Atweh, 2012). From starting effective school research on school and classroom ethos, research on student behavior in the classroom, to researching student problems about the social dynamics of race and gender. Previous Research found that classroom talk (a part of learning environment) is frequently not used to maximize children's studying - teacher talk dominates in the classroom while few effective oral interactions occur among students (Khong et al., 2019). Evidence that the learning environment will greatly impact student achievement appears (Kraft et al., 2016). If the learning environment is not supportive, student achievement will decrease. Experts have explored this relationship using data from schools in Chicago, California, Massachusetts, North Carolina, and New York City (Kraft et al., 2016). Other research said that there was a high level of acceptance of the framework as an effectual tool for designing and performing pedagogy (K. Alsharif \& Atweh, 2012). If not approached correctly, a classroom environment does not promote a positive learning environment (Hannah, 2013). Therefore, it can be seen that the classroom learning environment is an important key in achieving optimal learning outcomes. We focused on learning situation that we make in learning mathematics. To do so, we used the following framework.

One of learning frameworks that can encourage a supportive learning environment and also have positive impact upon the social and academic outcomes is Productive Pedagogies Framework (K. M. Alsharif, 2011; Hayes et al., 2020; Suhendra, 2015). The Productive Pedagogies Framework (PPF) is a learning framework with the goal of making valuable learning experiences for learners, regardless of their limitations and background, which will produce in notable improvements in the effectiveness and quality of mathematics learning (Bature, 2016; Bowes \& Tinning, 2015; Suhendra, 2015; Zohir \& Shaari, 2012). PPF also can make progressive change from the traditional teacher-centered teaching to a more studentcentered pedagogy and the study recommends they need to take on the PPF into the mathematics classroom (Bature, 2020; Suhendra \& Nurlaela, 2018). One dimension of this framework that supports creating a conducive learning environment is supportive classroom environment. This research aims to find the experience of students who feel the implementation of the Supportive Classroom Environment dimension when learning mathematics. Therefore, the authors are interested to report this research related to the classroom environment that supports learning by referring to the Productive Pedagogies Framework.

\section{B. METHODS}

We used qualitative methods. In this study, we involved in the situation and setting of the phenomenon under study. This research used a qualitative descriptive design. In this study, we focused on the learning situation that we created referring to the elements of the Supportive Classroom Environment of Productive Pedagogies Framework. Thus, it is hoped that we can describe the phenomenon of the learning process utilizing the Supportive Classroom Environment from the PPF in depth. There were 33 grade VII students (boys and girls) on average age of 13 years old from one of the Junior High Schools in Bandung participated in this study. Other qualitative research instruments used in this study include 1) Observation Sheet, which is a sheet containing a statement table which will be filled by the 
observer or observer; 2) Test, in the form of questions given at the end of the study to find out the outcomes of the learning which has been done.

The qualitative data analysis techniques that have been collected from the results of observations and tests. 1) Observation Sheet Data Analysis, obtained from observers' observations on teacher and student activities during the learning process. Observations were made in 5 meetings; 2) Analysis of Test Data Results will also strengthen to find out the results of the learning.

\section{RESULT AND DISCUSSION}

This research was implemented in one of junior high schools in Bandung. We made it 5 meeting times. In learning mathematics using the dimensions of the Classroom Environment that Supports the Productive Pedagogical Framework, we made three stages namely planning, implementing, and evaluating learning.

\section{Learning Plans}

We prepared several things, such as arranging learning indicators that use dimension of Supporting Classroom Environment, arranging preparation of lesson plans (RPP) and Student Worksheets (LKS). We adapted learning indicator from the elements present in the Supporting Classroom Environment dimension of the Productive Pedagogical Framework as looked in Table 1. In compiling lesson plans and worksheets, they are adjusted to the curriculum and syllabus used at the school.

Table 1. Learning Indicators Using Dimensions of the Supportive Classroom Environment from the Productive Pedagogies Framework

\begin{tabular}{cl}
\hline $\begin{array}{c}\text { Element of Supportive } \\
\text { Classroom Environment }\end{array}$ & \multicolumn{1}{c}{ General Indicators } \\
\hline Student Direction & $\begin{array}{l}\text { Learning gives students the opportunity to be involved in } \\
\text { determining the direction of learning activities from the technical } \\
\text { side. }\end{array}$ \\
\hline \multirow{2}{*}{ Social Support } & $\begin{array}{l}\text { Learning focuses on the atmosphere of learning to respect the } \\
\text { opinions of teachers and students and between students. }\end{array}$ \\
\cline { 2 - 3 } Learning shows a vibrant learning atmosphere. \\
\hline Academic Engagement & $\begin{array}{l}\text { Learning makes students actively involved. (Asking, working, } \\
\text { contributing to group activities). }\end{array}$ \\
\hline Explicit Quality & $\begin{array}{l}\text { The teacher explains the learning objectives so that they are easily } \\
\text { understood by students. }\end{array}$ \\
\hline Performance Criteria & $\begin{array}{l}\text { The teacher explains the activities that will be carried out during the } \\
\text { learning. }\end{array}$ \\
\hline Self-Regulation & $\begin{array}{l}\text { Learning guides students so they understand their learning needs. } \\
\text { participating in activities. }\end{array}$ \\
\hline
\end{tabular}

The preparation of lesson plans and worksheets is adjusted to the curriculum and syllabus used at the school, the 2013 curriculum. We also adapted the indicators to the Supportive Classroom Environment dimensions of the Productive Pedagogies Framework. 
The material presented in learning is algebraic form material consisting of two basic competencies that must be achieved. Following are the basic competencies which must be reached by students during the learning process.

3.5 Explain algebraic forms and carry out operations on algebraic forms (addition, subtraction, multiplication, and division).

4.5 Solve problems related to algebraic forms and operations on algebraic forms.

\section{Implementing the Dimensions}

During the implementation of learning using Supportive Classroom Environment of the Productive Pedagogies Framework, we were assisted by observers to observe us and student activities. It is intended to measure the achievement of learning indicators and the obstacles that occur when learning took place. Observations were made in 5 meetings.

\section{Evaluating Results}

Indicators of the dimensions of the Supportive Classroom Environment in the learning plan had been prepared. Supportive Classroom Environment dimension indicators in learning activities with the following details are in Table 2.

Table 2. Implementation of Supportive Classroom Environment

\begin{tabular}{|c|c|c|c|}
\hline $\begin{array}{c}\text { Observation } \\
\text { Objective }\end{array}$ & General Indicators & Fifth Learning Plan & Result of Fifth Observation \\
\hline $\begin{array}{c}\text { Student } \\
\text { Direction }\end{array}$ & $\begin{array}{l}\text { Learning gives } \\
\text { students the } \\
\text { opportunity to be } \\
\text { involved in } \\
\text { determining the } \\
\text { direction of } \\
\text { learning activities } \\
\text { from the technical } \\
\text { side. }\end{array}$ & $\begin{array}{l}\text { This indicator is applied } \\
\text { in the technical } \\
\text { discussion of worksheet. } \\
\text { It is hoped that students } \\
\text { can learn to be } \\
\text { responsible } \\
\text { themselves for } \\
\text { they take part in } \\
\text { determining } \\
\text { direction of learning } \\
\text { activities. }\end{array}$ & $\begin{array}{l}\text { Based on the desire of many } \\
\text { students who want to be } \\
\text { explained again about the } \\
\text { material being studied and also } \\
\text { since the worksheets have not } \\
\text { been completely finished, the } \\
\text { teacher decides at this meeting } \\
\text { not to move material, so the } \\
\text { material being studied is the } \\
\text { division of algebraic forms. }\end{array}$ \\
\hline \multirow[t]{2}{*}{$\begin{array}{c}\text { Social } \\
\text { Support }\end{array}$} & $\begin{array}{l}\text { Learning focuses on } \\
\text { the atmosphere of } \\
\text { learning to respect } \\
\text { the opinions of } \\
\text { teachers and } \\
\text { students and } \\
\text { between students. }\end{array}$ & $\begin{array}{l}\text { This indicator is applied } \\
\text { when someone is } \\
\text { speaking in front of the } \\
\text { class, or between } \\
\text { students discussing in } \\
\text { groups. }\end{array}$ & $\begin{array}{l}\text { This indicator is fulfilled when } \\
\text { the teacher makes an } \\
\text { apperception by asking } \\
\text { questions, students are of an } \\
\text { opinion while others hear the } \\
\text { opinion. In addition, this } \\
\text { indicator is met when there are } \\
\text { groups who present in front of } \\
\text { the class. }\end{array}$ \\
\hline & $\begin{array}{l}\text { Learning shows a } \\
\text { vibrant learning } \\
\text { atmosphere. }\end{array}$ & $\begin{array}{l}\text { This indicator is applied } \\
\text { during the learning process, } \\
\text { starting from the teacher's } \\
\text { friendly and good attitude } \\
\text { and the existence of rewards } \\
\text { when students dare to } \\
\text { answer. }\end{array}$ & $\begin{array}{l}\text { Giving rewards to students who } \\
\text { are able to answer, create a } \\
\text { vibrant learning atmosphere. } \\
\text { This is reinforced by the game } \\
\text { before learning. }\end{array}$ \\
\hline
\end{tabular}




\begin{tabular}{|c|c|c|c|}
\hline $\begin{array}{c}\text { Observation } \\
\text { Objective }\end{array}$ & General Indicators & Fifth Learning Plan & Result of Fifth Observation \\
\hline $\begin{array}{c}\text { Academic } \\
\text { Engagement }\end{array}$ & $\begin{array}{l}\text { Learning makes } \\
\text { students actively } \\
\text { involved. (Asking, } \\
\text { working, } \\
\text { contributing to } \\
\text { group activities). }\end{array}$ & $\begin{array}{l}\text { This indicator is used } \\
\text { when students pay } \\
\text { attention, work in } \\
\text { groups, ask questions } \\
\text { when there is something } \\
\text { which is not understood. }\end{array}$ & $\begin{array}{l}\text { Students who seemed to pay } \\
\text { attention to explanations from } \\
\text { the teacher, student involvement } \\
\text { in groups, work on LKS, and the } \\
\text { presence of students who dared } \\
\text { to present indicated this } \\
\text { indicator was fulfilled. }\end{array}$ \\
\hline \multirow[t]{2}{*}{$\begin{array}{l}\text { Explicit } \\
\text { Quality } \\
\text { Performance } \\
\text { Criteria }\end{array}$} & $\begin{array}{l}\text { The teacher } \\
\text { explains the } \\
\text { learning objectives } \\
\text { so that they are } \\
\text { easily understood } \\
\text { by students. }\end{array}$ & $\begin{array}{l}\text { This indicator is applied } \\
\text { at the beginning of } \\
\text { learning, especially after } \\
\text { apperception activities. }\end{array}$ & $\begin{array}{l}\text { This indicator appeared when } \\
\text { the teacher delivered the } \\
\text { learning objectives to be carried } \\
\text { out at the meeting. }\end{array}$ \\
\hline & $\begin{array}{l}\text { The teacher } \\
\text { explains the } \\
\text { activities that will } \\
\text { be implemented } \\
\text { during the learning. }\end{array}$ & $\begin{array}{l}\text { This indicator is applied } \\
\text { at the beginning of } \\
\text { learning, especially after } \\
\text { apperception activities. }\end{array}$ & $\begin{array}{l}\text { Students are seen responding to } \\
\text { the explanation of the activities } \\
\text { that will be carried out with a } \\
\text { time agreement that has been } \\
\text { made together. This indicates } \\
\text { that the indicator is fulfilled. }\end{array}$ \\
\hline \multirow[t]{2}{*}{$\begin{array}{c}\text { Self- } \\
\text { Regulation }\end{array}$} & $\begin{array}{l}\text { Learning guides } \\
\text { students so they } \\
\text { understand their } \\
\text { learning needs. }\end{array}$ & $\begin{array}{l}\text { This indicator is applied } \\
\text { when the teacher and } \\
\text { students discuss the } \\
\text { benefits of learning } \\
\text { algebraic material. }\end{array}$ & $\begin{array}{l}\text { The teacher re-links the } \\
\text { importance of learning algebraic } \\
\text { division of learning, at least by } \\
\text { linking learning needs towards } \\
\text { the Final Student Assessment. }\end{array}$ \\
\hline & $\begin{array}{l}\text { Learning } \\
\text { unconsciously } \\
\text { makes students } \\
\text { enthusiastic about } \\
\text { participating in } \\
\text { activities. }\end{array}$ & $\begin{array}{l}\text { This indicator appears } \\
\text { when the teacher } \\
\text { provides an atmosphere } \\
\text { that is uplifting and fun, } \\
\text { and there is a reward. }\end{array}$ & $\begin{array}{l}\text { Students were seen competing } \\
\text { to answer the questions the } \\
\text { teacher gave. This indicates that } \\
\text { students are enthusiastic about } \\
\text { learning mathematics. }\end{array}$ \\
\hline
\end{tabular}

\section{Student Learning Outcomes}

Student learning outcomes during mathematics learning utilizing the Supportive Classroom Environment dimension of the Productive Pedagogies Framework were obtained through a learning evaluation (Test) at the end of the study after 5 meetings. The test is conducted at the end of the research in the form of a description item. The material used is to state algebraic forms, addition, subtraction, multiplication and division of algebraic forms. The results of the test data are used to strengthen the depiction of the results of the implementation of the supportive classroom environment dimension after learning is done. The questions are in Figure 1. 


\section{PROBLEMS OF ALGEBRA|FORM MATERIALS}

1) One day Nino bought 3 boxes of noodles for the needs of the celebration at her house. After taking it home, the noodles turned out to be lacking. Then Nino bought another 10 packs of noodles. State the algebraic form of the noodle that Nino bought.

2) Mrs. Susi bought $10 \mathrm{~kg}$ of chili, $13 \mathrm{~kg}$ of tomatoes, and $4 \mathrm{~kg}$ of carrots. Because it was stored too long, $3 \mathrm{~kg}$ of chili, $4 \mathrm{~kg}$ of tomatoes, and $2 \mathrm{~kg}$ of carrots turned out rotten. If the price of chili, tomato, and carrots for each kilogram is successively $\mathrm{x}$ rupiah, $\mathrm{y}$ rupiah, and $z$ rupiah, determine the price of the remaining Mrs. Susi's items in algebraic form.

3) Determine the product of the following algebraic forms.

a. $7(3 \mathrm{~m}-5)$

b. $(p+3)(6 p-8)$

4) Erik has a rectangular tomato garden. The length of Mr. Erik's tomato garden is $10 \mathrm{~m}$ longer than his width. What is Pak Erik's tomato garden area?

5) Nirmala has a strawberry garden. If stated in algebraic form, the area of the Nirmala strawberry garden is $x^{\wedge} 2+3 x-10$ units area, and the length is $x+5$ units length. Determine the width of the Nirmala strawberry garden in algebraic form.

Figure 1. Algebra Form Material Test

The learning indicators tested in the evaluation of learning are in Table 3.

Table 3. Learning Indicators on Each Question

\begin{tabular}{cl}
\hline Number & \multicolumn{1}{c}{ Indicators } \\
\hline 1 & States algebraic forms \\
2 & Solve problems related to the addition and subtraction operations on the algebraic form \\
3 & Perform multiplication operations of algebraic forms \\
4 & Solve problems related to algebraic multiplication operations \\
5 & Solve problems related to algebraic shape division operations \\
\hline
\end{tabular}

Students who carry out learning evaluations consist of 33 people. The average score of students in the evaluation of learning is 45 . Meanwhile, the minimum score of mathematics in the school concerned is 70 . This means the average score of students in the evaluation of learning is still below the minimum score. We divided the three groups of students based on the highest grade, the mid-grade, and the lowest grade. Students who get the highest score (called the upper group) will be taken 27\%, the lowest score (called the lower group) taken $27 \%$, and students who get the middle score (called the middle group) will be taken $46 \%$ (Arikunto, 2016). Therefore, from 33 students, 9 students from the upper group, 15 students from the middle group and 9 students from the lower group. These is example of student' answer in upper group whose learning outcomes have exceeded the minimum score (in Figure 2), in middle group whose learning outcomes have exceeded the minimum score (in Figure 3), and in lower group whose learning outcomes didn't have exceeded the minimum score (in Figure 4). 
Jawaban

(1). $3 u+10(u=$ dus mie $)$

(2). $10 \mathrm{~kg}-3 \mathrm{~kg}+13 \mathrm{~kg}-4 \mathrm{~kg}+4 \mathrm{~kg}-2 \mathrm{~kg}$ $7 \mathrm{kgl}+9 \mathrm{~kg} \mathrm{y}^{3}+2 \mathrm{~kg} z^{2}$ 49 rupia + 81 rupia + 4 rupla

(3). a. $7(3 m-5)$

$$
21 m-35
$$

b. $(p+3)(6 p-8)$

$6 p^{2}-8 p+18 p-24$

$6 p^{2}+10 p-24$ (4) Panjang: lom lebih panjang dari lebarnya $\rightarrow$ lebar : $u \quad L=P \times 1$
Luas : ? $=(x+10) u$ $=x^{2}+10 x$

(5) $L=$ luas: Panjang

$L: x^{2}+3 x-10: x+5$ $u+5 \sqrt{u^{2}+3 u-10} \quad v$

$L=x-2$ $\frac{u^{2}+5 u}{-2 u-10}$

Figure 2. One of Student's Answer in Upper Group

$1 x=$ kardus

$y=$ Bungkus mie $\} 3 x+10 y$ us

$210 x-3 x=7 x$

$13 y-4 y=9 y \quad 3 x+9 y+2 z$

$4 z-2 z=2 z$

$32(3 m-5)=21 m-35$ (a)

$(p+3)(6 p-\theta)=6 p^{2}+(-\theta p)+10 p+(-24)$ $=6 p^{2}-\frac{16 p}{26 p}-24$

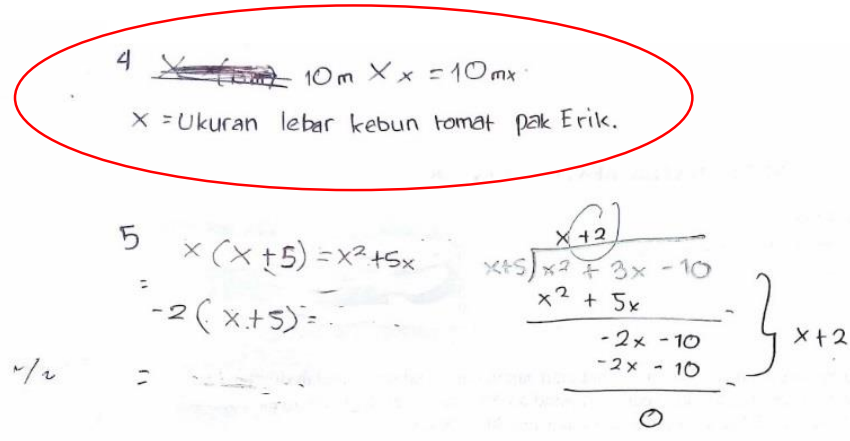

Figure 3. One of Student's Answer in Middle Group

1. Oik: 3 Dus me, kurang dan membeli lagi b dus mie
Dit: Bentik al jabar

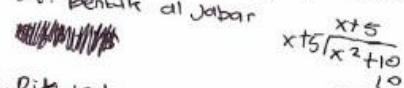

2. Dik $10 \mathrm{~kg}$ cabai, $13 \mathrm{~kg}$ 10mat

$3 \mathrm{~kg}$, $13 \mathrm{~kg}$ tomat, $4 \mathrm{~kg}$ wortel

hangama $4 \mathrm{~kg}$ tomat, $2 \mathrm{~kg}$ wortel busuk

Drt: harga bentuk

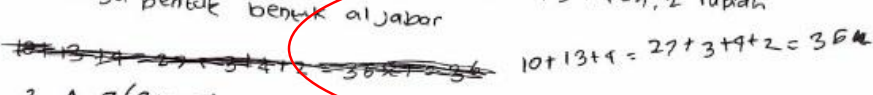

3. A. $7(3 m-5)=7 \times 5=35 \times$

B. $(p+3)(6 p-8)=6 p \times p=6 p-$

4. $=8 \times 3=24$

4. Dikikebun tomat benuk peserg; parjang ukuran $10 \mathrm{~m}$ rebih painang dan

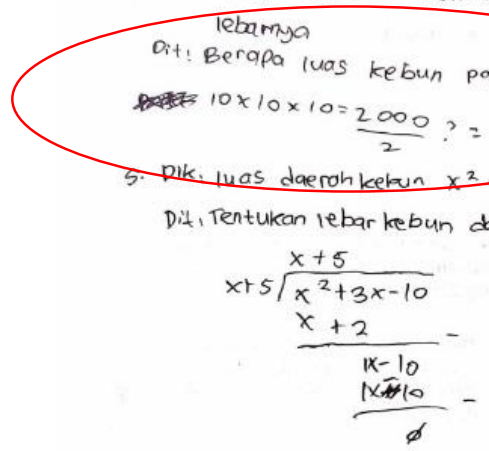

Figure 4. One of Student's Answer in Lower Group 
The student achievements based on learning indicators are in Table 4 .

Table 4. Student Achievements in each Group

\begin{tabular}{|c|c|c|c|}
\hline Indicators & $\begin{array}{c}\text { Student Learning } \\
\text { Outcomes in Upper } \\
\text { Group }\end{array}$ & $\begin{array}{l}\text { Student Learning } \\
\text { Outcomes in Middle } \\
\text { Group }\end{array}$ & $\begin{array}{c}\text { Student Learning } \\
\text { Outcomes in Lower } \\
\text { Group }\end{array}$ \\
\hline $\begin{array}{l}\text { States } \\
\text { algebraic } \\
\text { forms }\end{array}$ & $\begin{array}{l}\text { Students can turn } \\
\text { information on questions } \\
\text { into notations in algebraic } \\
\text { form. Thus this indicator is } \\
\text { fulfilled. }\end{array}$ & $\begin{array}{l}\text { Students can turn } \\
\text { information on questions } \\
\text { into notations in algebraic } \\
\text { form. Thus this indicator is } \\
\text { fulfilled. }\end{array}$ & $\begin{array}{l}\text { Students only rewrite } \\
\text { information on the } \\
\text { problem. This shows } \\
\text { that students have not } \\
\text { been able to turn } \\
\text { information on } \\
\text { questions into } \\
\text { notations in algebraic } \\
\text { form. }\end{array}$ \\
\hline $\begin{array}{l}\text { Solve } \\
\text { problems } \\
\text { related to the } \\
\text { addition and } \\
\text { subtraction } \\
\text { operations on } \\
\text { the algebraic } \\
\text { form }\end{array}$ & $\begin{array}{l}\text { Students can solve the } \\
\text { problem of reducing this } \\
\text { problem. But at the end of } \\
\text { this answer there is a } \\
\text { mistake, namely students } \\
\text { squaring the results. This is } \\
\text { due to the inaccuracy of } \\
\text { students in reading } \\
\text { questions. }\end{array}$ & $\begin{array}{l}\text { Students can solve the } \\
\text { problem of reducing this } \\
\text { problem well. So this } \\
\text { indicator can be said to be } \\
\text { fulfilled. }\end{array}$ & $\begin{array}{l}\text { Students have not been } \\
\text { able to solve the } \\
\text { problem of reducing } \\
\text { this problem. So this } \\
\text { indicator is not met. }\end{array}$ \\
\hline $\begin{array}{l}\text { Perform } \\
\text { multiplication } \\
\text { operations of } \\
\text { algebraic } \\
\text { forms }\end{array}$ & $\begin{array}{l}\text { Students can solve this } \\
\text { problem well. Students can } \\
\text { operate multiplications of } \\
\text { algebraic forms. }\end{array}$ & $\begin{array}{l}\text { Students can solve this } \\
\text { problem well. Students can } \\
\text { operate multiplications of } \\
\text { algebraic forms. But there } \\
\text { are still errors in the } \\
\text { positive and negative signs. }\end{array}$ & $\begin{array}{l}\text { Students only work on } \\
\text { one stage only. This } \\
\text { shows that students } \\
\text { are not yet adept at } \\
\text { performing } \\
\text { multiplication } \\
\text { operations in algebraic } \\
\text { forms. }\end{array}$ \\
\hline $\begin{array}{l}\text { Solve } \\
\text { problems } \\
\text { related to } \\
\text { algebraic } \\
\text { multiplication } \\
\text { operations }\end{array}$ & $\begin{array}{l}\text { Students can declare } \\
\text { information from problems } \\
\text { into models of algebraic } \\
\text { forms. Students can solve } \\
\text { these problems well. }\end{array}$ & $\begin{array}{l}\text { Students have not been } \\
\text { able to express information } \\
\text { from problems into } \\
\text { algebraic form models. } \\
\text { This is likely students do } \\
\text { not understand the } \\
\text { purpose of the question. }\end{array}$ & $\begin{array}{l}\text { Students are able to } \\
\text { express information } \\
\text { from the questions. } \\
\text { But the students } \\
\text { seemed not to } \\
\text { understand the } \\
\text { solution that had to be } \\
\text { done. }\end{array}$ \\
\hline $\begin{array}{l}\text { Solve } \\
\text { problems } \\
\text { related to } \\
\text { algebraic } \\
\text { shape } \\
\text { division } \\
\text { operations }\end{array}$ & $\begin{array}{l}\text { Students can solve this } \\
\text { problem well, and students } \\
\text { also show how the work is } \\
\text { done. }\end{array}$ & $\begin{array}{l}\text { Students can solve this } \\
\text { problem well, but there are } \\
\text { still errors in the positive } \\
\text { and negative signs in the } \\
\text { answers. This is probably } \\
\text { caused by the inaccuracy of } \\
\text { students in working on the } \\
\text { problems. }\end{array}$ & $\begin{array}{l}\text { Students only rewrite } \\
\text { information on the } \\
\text { problem. In the } \\
\text { process, there is a } \\
\text { mistake in the } \\
\text { calculation so students } \\
\text { are said to have not } \\
\text { been able to solve } \\
\text { problems related to } \\
\text { the operation of the } \\
\text { division of algebraic } \\
\text { forms. }\end{array}$ \\
\hline
\end{tabular}


From the findings explained, we found that the productive pedagogies framework, specifically the supportive classroom environment dimension, has not been able to encourage students in the lower group. However, this learning can help students get an optimal learning experience in middle group and upper group students. The learners turned out to be more enthusiastic to react to the instructors' inquiries and to communicate their thoughts. The interactions between learners also became more often and positive. Students started to lift their hands all the more frequent to respond their teachers' inquiries or to remark on what their friends said. The utilization of learning groups, combined with supportive classroom environment, guided to improved interactions. Supportive classroom environment is expected to support high intellectual quality and connectedness to guarantee that students can accomplish learning goal (Zohir \& Shaari, 2012). Gifted teenagers in middle and high school profit by classroom environments that help their emotional and social development (Hébert et al., 2014). This finding is in line with previous research that the application of the Productive Pedagogies framework, learners found mathematics classes to be more accessible and attractive (in case of understanding concepts), and was found to increase students' engagement (Suhendra, 2015). Students who has been feeling supported in their academic engagement are additionally having more positive attitudes, are motivated to learn, attend school more regularly and are engaged, and also have prominent academic success (Cipriano et al., 2019; Oberle, 2018). This framework will help enhancing teachers' teaching skill and will produce to a greater performance (Bature et al., 2015; Espinosa et al., 2018; Suhendra, 2015). This also corroborates previous research which found that implementing a Productive Pedagogical Framework enhances class involvement and participation (Bature, 2016; Tanko, 2012).

\section{CONCLUSION AND SUGGESTIONS}

Based on the findings and discussion, we conclude that, implementing Supportive Classroom Environment can further encourage students in upper group to achieve more optimal learning outcomes. Students become more excited when learning has implemented. This learning can be said to encourage middle group students to get optimal learning outcomes. Starting with learning mathematics that students like, it is hoped that this will have an impact on students who like mathematics so that it will gradually lead to optimal learning outcomes. This learning has not been able to encourage students in lower group and need time to understand the lesson in order to achieve results according to learning indicators. These students need more help from the teacher in mastering mathematics learning material. This study used only one learning model. Therefore, for the effective implementation of supportive classroom environment, we suggest to use different learning models at each meeting.

\section{ACKNOWLEDGEMENT}

I am especially thankful to Al Jupri, M. Sc., Ph. D., in Universitas Pendidikan Indonesia for advice in writing of this manuscript. I thank to SMPN 26 Bandung and also to mathematics teacher, Dra. Ida Supartini for allowing me to conduct my research in her class. I would never have completed this without their guidance.

\section{REFERENCES}

Alsharif, K., \& Atweh, B. (2012). Productive pedagogies as framework to improve preservice teachers' practices. International Journal of Learning, 18(4), 223-236. https://doi.org/10.18848/1447-9494/cgp/v18i04/47572

Alsharif, K. M. (2011). Science and Mathematics Education Centre Towards Quality Teacher 
Education: Productive Pedagogies as a Framework for Saudi Pre-service Teachers Training in Mathematics Education (Issue December).

Arikunto, S. (2016). Dasar-dasar Evaluasi Pendidikan. Bumi Aksara.

Bature, I. J. (2016). Achieving Quality Mathematics Classroom Instruction through Productive Pedagogies. International Journal of Educational Methodology, 2(1), 1-18. https://doi.org/10.12973/ijem.2.1.1

Bature, I. J. (2020). Mathematics Teachers Reflection on the Role of Productive Pedagogies in Improving their Classroom Instruction. International Journal of Educational Methodology, 6(2), 319-335. https://doi.org/10.12973/ijem.6.2.319

Bature, I. J., Jackson, J. J., \& Kemi, A. (2015). Introducing Productive Pedagogies to Nigerian Mathematics Classroom through Collaborative Action Research Using a Community of Practice Approach. International Journal of Learning, Teaching and Educational Research, 11(3), 41-58.

Bowes, M., \& Tinning, R. (2015). Productive pedagogies and teachers' professional learning in physical education. Asia-Pacific Journal of Health, Sport and Physical Education, 6(1), 93109. https://doi.org/10.1080/18377122.2014.997863

Cipriano, C., Barnes, T. N., Pieloch, K. A., Rivers, S. E., \& Brackett, M. (2019). A multilevel approach to understanding student and teacher perceptions of classroom support during early adolescence. Learning Environments Research, 22(2), 209-228. https://doi.org/10.1007/s10984-018-9274-0

Espinosa, A. A., Datukan, J., Butron, B., \& Tameta, A. D. (2018). Perceptions of pre-service chemistry teachers on the utilization of productive lesson study as a framework for teaching and learning. International Journal for the Scholarship of Teaching and Learning, 12(1), 1-7. https://doi.org/10.20429/ijsotl.2018.120109

Hannah, R. (2013). ScholarWorks at WMU The Effect of Classroom Environment on Student Learning The Effect of Classroom Environment on Student Learning Ryan Hannah Lee Honors College Honors Thesis Thesis Chair : Dr . Dini Metro-Roland Committee Member: Prof. Kelly Killen.

Hayes, D., Mills, M., Christie, P., \& Lingard, B. (2020). Teachers and schooling making a difference: Productive pedagogies, assessment and performance.

Hébert, T. P., Corcoran, J. A., Coté, J. M., Ene, M. C., Leighton, E. A., Holmes, A. M., \& Padula, D. D. (2014). It's Safe to Be Smart. Gifted Child Today, 37(2), 95-101. https://doi.org/10.1177/1076217514520966

Khong, T. D. H., Saito, E., \& Gillies, R. M. (2019). Key issues in productive classroom talk and interventions. Educational Review, 31(3), 334-349. https://doi.org/10.1080/00131911.2017.1410105

Kraft, M. A., Marinell, W. H., \& Shen-Wei Yee, D. (2016). School Organizational Contexts, Teacher Turnover, and Student Achievement: Evidence From Panel Data. American Educational Research Journal, 53(5), 1411-1449. https://doi.org/10.3102/0002831216667478

Oberle, E. (2018). Early Adolescents' Emotional Well-Being in the Classroom: The Role of Personal and Contextual Assets. Journal of School Health, 88(2), 101-111. https://doi.org/10.1111/josh.12585

Sholihah, D. A., \& Mahmudi, A. (2015). Keefektifan Experiental Learning Pembelajaran Matematika MTs Materi Bangun Ruang Sisi Datar. Jurnal Riset Pendidikan Matematika, 2(2), 175. https://doi.org/10.21831/jrpm.v2i2.7332

Siregar, N. R. (2017). Persepsi Siswa Pada Pelajaran Matematika: Studi Pendahuluan Pada Siswa yang Menyenangi Game. Prosiding Temu Ilmiah X Ikatan Psikologi Perkembangan Indonesia, 224-232.

Suhendra. (2015). Science and Mathematics Education Centre Reforming Mathematics 
Education in Indonesia Using the Productive Pedagogies Framework Suhendra (Issue April).

Suhendra, M., \& Nurlaela, E. (2018). Revitalization of Mathematical Education Through Applying Productive Pedagogies Framework. 160(Incomed 2017), 179-187. https://doi.org/10.2991/incomed-17.2018.39

Tanko, M. G. (2012). Teaching practical numeracy through social justice pedagogy: Case study of $\mathrm{Abu}$ Dhabi Women's College (Issue March 2012). http://espace.library.curtin.edu.au/cgi-bin/espace.pdf?file=/2012/08/09/file_1/186782 Zohir, M., \& Shaari, A. (2012). Exploring the Classroom Practice of Productive Pedagogies of the Malaysian Secondary School Geography Teacher. Review of International Geographical Education Online, 2(2), 146-164. 